\title{
Characterization of Phytophthora capsici Causing Foliar and Pod Blight of Snap Bean in Michigan
}

\author{
A. J. Gevens, former graduate student, Department of Plant Pathology, Michigan State University, East Lansing \\ 48824; R. S. Donahoo and K. H. Lamour, Department of Entomology and Plant Pathology, The University of Ten- \\ nessee, Knoxville 37996; and M. K. Hausbeck, Department of Plant Pathology, Michigan State University, East \\ Lansing 48824
}

\begin{abstract}
Gevens, A. J., Donahoo, R. S., Lamour, K. H., and Hausbeck, M. K. 2008. Characterization of Phytophthora capsici causing foliar and pod blight of snap bean in Michigan. Plant Dis. 92:201209.

Green and yellow snap bean plants with water-soaked foliar lesions, stem necrosis, pod blight, and overall plant decline were observed in four commercial fields in three Michigan counties during 2003 to 2005. All fields were cropped to cucurbits that exhibited symptoms of Phytophthora capsici infection in recent years. In all, 680 isolates of $P$. capsici were obtained from bean stems, petioles, leaves, and pods; the pathogen was not recovered from roots. Koch's postulates were completed with representative isolates, confirming $P$. capsici as the causal organism. Select isolates also were pathogenic on cucumber fruit, causing symptoms consistent with $P$. capsici infection. The majority of the $P$. capsici isolates collected were sensitive to the fungicide mefenoxam and were of the A1 mating type. Under laboratory conditions, six $P$. capsici isolates from snap bean (2003) were pathogenic on 12 different commercial bean cultivars, including soybean. Infected bean plants exhibited water-soaked lesions, foliar necrosis, and wilting. We subjected 131 isolates collected from 2003 and 2004 to amplified fragment length polymorphism analysis to investigate diversity among isolates and geographical populations and to determine whether bean $P$. capsici isolates were similar to isolates from a cucurbit host. This is the first indepth study of $P$. capsici on snap bean in Michigan. Although bean cultivars previously were considered a suitable rotation for crops susceptible to $P$. capsici, this is no longer a recommended practice.
\end{abstract}

Additional keyword: etiology

Crop losses due to the soilborne, fungal-like oomycete Phytophthora capsici (Leonian) have been documented in many vegetable production regions $(5,12,14$, 23,27). Michigan has over 79,000 acres of solanaceous and cucurbitaceous crops that are susceptible to $P$. capsici and ranks as the top state in the United States in pickling cucumber production (16). An increase in infested acreage and loss of land due to increased urbanization occurring across vegetable production areas in Michigan have limited growers' ability to find noninfested land for crop rotation $(12,14,23,27)$. The fungicide mefenoxam commonly was

Corresponding author: M. K. Hausbeck

E-mail: hausbec1@msu.edu

Current address of A. J. Gevens: Plant Pathology Department, University of Florida IFAS, Gainesville 32611 .

Accepted for publication 11 September 2007.

doi:10.1094/PDIS-92-2-0201

(C) 2008 The American Phytopathological Society used to manage $P$. capsici; however, development of resistant pathogen populations limits its usefulness $(18,21,22,27)$.

$P$. capsici produces several spore types, each with a unique role in the disease cycle $(6,7,34)$. Oospores remain viable for extended periods of time and result from the sexual interaction of $\mathrm{A} 1$ and $\mathrm{A} 2$ mating types and overwinter in host tissue and field soil $(6,7,17,35)$. Populations of $P$. capsici studied from Michigan fields have had both A1 and A2 mating types present in an approximate ratio of 1:1 (18). Disease is initiated each spring when a susceptible crop is planted in an infested field and environmental conditions favor the germination of oospores $(6,7)$. Sporangia and mycelia develop on infected host tissue under warm $\left(25\right.$ to $\left.28^{\circ} \mathrm{C}\right)$, wet conditions $(1,2,4,6,15,24,29)$. Sporangia and zoospores are secondary inocula that can be produced repeatedly during the growing season, causing rapid escalation of disease $(6,7)$. Under free water conditions, each sporangium releases 20 to 40 motile zoospores, each capable of causing infection $(6,7,29)$.
Physiological races exist within P. capsici, indicating diversity among isolates in pathogenicity or virulence (13-15,23, $25,26,33)$. Although diversity in virulence among $P$. capsici isolates from multiple hosts has been noted, it is questionable whether this diversity reflects true host specificity. The concept of host specificity of $P$. capsici has been explored; however, studies have been limited, often relying on a single inoculation method under a narrow set of environmental conditions $(26,32)$. The susceptibility of plants to $P$. capsici is significantly impacted by the method of inoculation, inoculum density, and environmental conditions $(15,23)$.

In Michigan, bean crops, including dry edible bean cultivars (pinto, kidney, cranberry, and lima), snap bean (green and yellow snap and Romano), and soybean, commonly are grown in rotation with cucurbits (31). Dry edible bean cultivars are susceptible to P. megasperma (Drechsler), $P$. nicotianae (Breda de Haan), and $P$. phaseoli (Thaxt.) (7,31), whereas snap beans are susceptible to the latter of the two species $(7,31)$. Soybean is susceptible to $P$. sojae and P. megasperma (7). In 2000 and 2001, $P$. capsici was isolated from diseased lima bean plants growing in commercial fields in Delaware, Maryland, and New Jersey (5). Prior to this time, there was just one report of $P$. capsici causing natural infection of pods and stems of lima bean (Phaseolus lunatus) which occurred in Cordoba, Argentina in 1950 (8). In Michigan, Phytophthora capsici first was isolated from green snap bean in 2003 from commercial fields with a history of zucchini cropping and $P$. capsici infestation $(10,12)$. The identification of $P$. capsici on snap bean in Michigan causes concern not only for leguminaceous crops but also for cucurbitaceous and solanaceous crops. Additionally, this finding complicates the crop rotation scheme (approximately 2 years out of a susceptible crop) currently used by many growers to manage the build-up of $P$. capsici inoculum in field soils (12).

The host range of $P$. capsici under natural, field conditions may differ from the host range under artificial, laboratory con- 
ditions. Laboratory inoculations of $P$. capsici on snap bean, lima bean, and soybean resulted in resistant plant responses in a 1967 study (28). However, in the same study, broad bean (Vicia faba L.) was susceptible to root rot (28). In a 1955 study, kidney bean plants were susceptible to $P$. capsici under laboratory conditions when grown from seed in infested soil (3). The biology and epidemiology of $P$. capsici on bean (Phaseolus spp. and Glycine max) are not well understood. With the identification of Leguminosae as a new natural host family for $P$. capsici, it is important to elucidate the etiology of the pathogen on bean for the development of appropriate crop rotation and disease management strategies.

Phenotypic characterization of $P$. capsici isolates from snap bean can indicate diversity of a field population and sensitivity to fungicides such as mefenoxam, which may

Table 1. Bean cultivars included in laboratory Phytophthora capsici pathogenicity screen

\begin{tabular}{ll}
\hline Genus, species & \multicolumn{1}{c}{ Cultivar $^{-}$} \\
\hline Phaseolus lunatus & Bush Lima $^{\mathrm{a}}$ \\
P. vulgaris var. humilis & Fordhook Standard $^{\mathrm{a}}$ \\
& Bush Tenderpod $^{\mathrm{a}}$ \\
& Bush Contender $^{\mathrm{a}}$ \\
P. vulgaris var. vulgaris & Pole Bean $^{\mathrm{a}}$ \\
& Kentucky Wonder Pole $^{\mathrm{a}}$ \\
P. vulgaris & Cranberry Soup Bean $^{\mathrm{b}}$ \\
& Gold Mine $^{\mathrm{a}}$ \\
& Black Turtle $^{\mathrm{a}}$ \\
& Blue Lake White Seed $^{\mathrm{a}}$ \\
& HyStyle $^{\mathrm{c}}$ \\
Glycine max & Soybean AG2403 $^{\mathrm{d}}$ \\
\hline
\end{tabular}

a W. Atlee Burpee \& Co., Warminster, PA.

b Syngenta Seeds, Inc., Rogers Brand Vegetable Seeds, Boise, ID.

c Harris Moran Seed Co., Modesto, CA.

d Asgrow Seed Co., Monsanto Co., St. Louis.

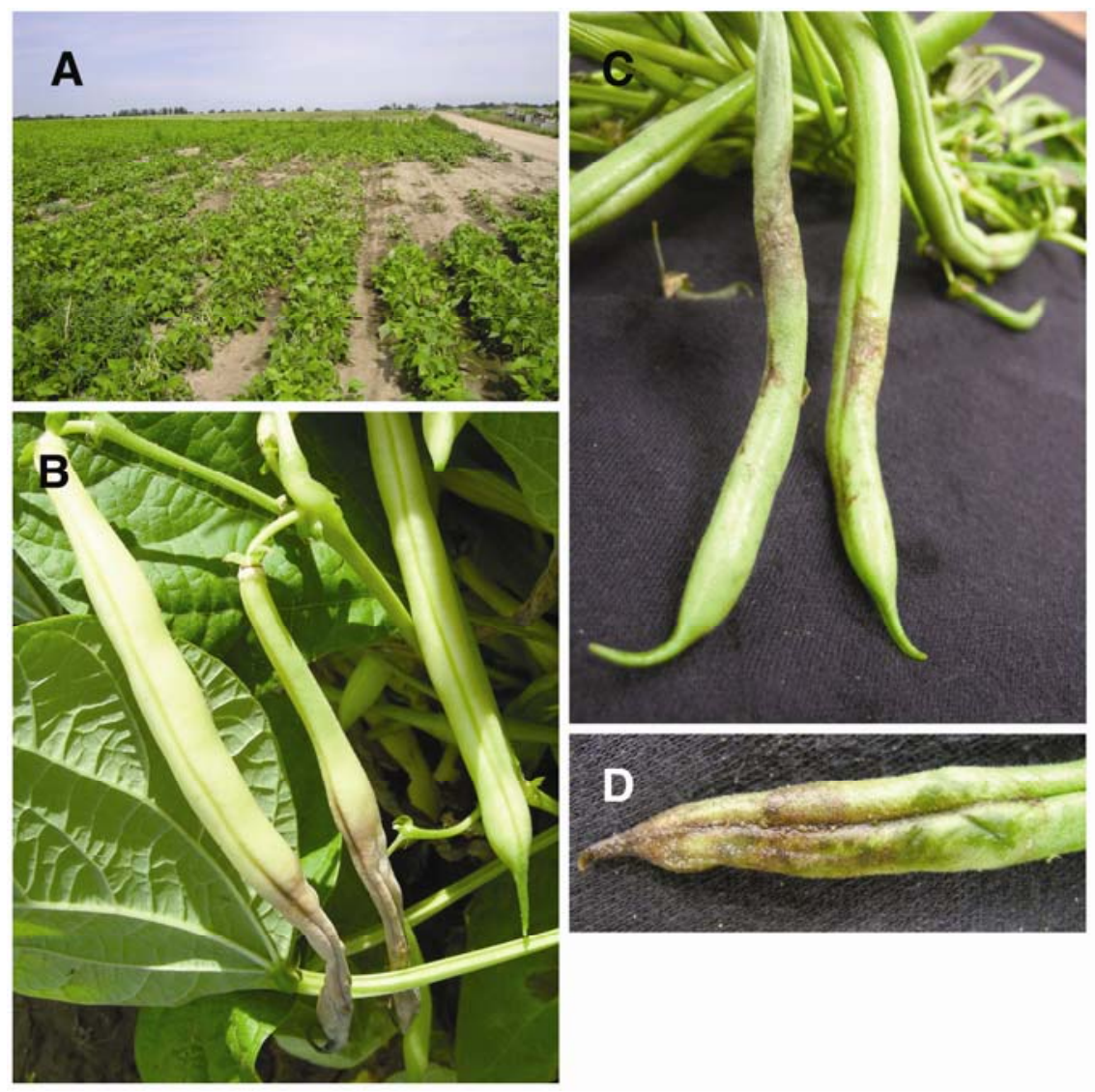

Fig. 1. Field and pod symptoms of Phytophthora capsici on snap bean. A, Field symptoms of P. capsici on yellow snap bean from Van Buren County, MI in July 2005. Note localized circular pattern of plant decline and death, and association of plant decline with the surface water drainage pattern. B, Infected pods of yellow snap bean 'Sunrae' from Van Buren County, MI, 2005. C and D, Infected pods of green snap bean 'HyStyle' from Cass County, MI, 2004. C, Lesions on pods are dark brown and sunken. D, Note brown, water-soaking symptoms on pod tip where pod made contact with the soil.

aid in management. Evaluation of the genetic structure of the pathogen population also may detect subdivisions among populations within a particular geographical region and may reveal host or tissue specificity. Our research objectives were (i) confirming pathogenicity of $P$. capsici isolated from bean cultivars, (ii) determining whether $P$. capsici isolates from snap bean were pathogenic on cucumber fruit, (iii) characterizing the isolates of $P$. capsici from snap bean by phenotypic and genotypic analyses, and (iv) assessing the susceptibility of several bean cultivars to $P$. capsici.

\section{MATERIALS AND METHODS}

Sample collection and pathogen identification. Symptomatic and asymptomatic snap bean plants were collected from four commercial fields in Michigan which exhibited varying levels of $P$. capsici disease incidence and severity. All snap beans sampled were growing in fields known to be infested with $P$. capsici. In recent years, the fields had been cropped primarily to cucurbits, including summer and winter squash and cucumbers, that had become infected by $P$. capsici. Two green snap bean fields in Oceana County were sampled in 2003. Field 1 was 50 acres and exhibited severe disease symptoms in one corner of the field. Field 2 was 40 acres and exhibited moderate disease symptoms in several areas of the field. The Cass County field (50 acres of green snap bean cv. HyStyle, 2004) exhibited moderate disease symptoms in several areas of the field, and the Van Buren County field (250 acres of yellow snap bean cv. Sunrae, 2005) exhibited severe disease symptoms throughout the entire field. In all, 50 to 200 plants exhibiting a range of disease symptoms (from healthy to dead) were collected from each of the four fields. Most of the plant samples were taken from areas of the fields with plants exhibiting water-soaked lesions on the foliage and wilting. Asymptomatic plants (approximately $25 \%$ of all plants collected) were collected from each field by moving through a field in an Xshaped pattern and randomly selecting plants at 10 sites for collection.

Leaf, petiole, stem, crown, and root tissues from symptomatic and asymptomatic bean plants were excised, surface sterilized with $70 \%$ ethanol for $10 \mathrm{~s}$, blotted dry with sterile paper towel, and plated onto benomyl, ampicillin, rifampicin, and pentachloronitrobenzene (BARP)-amended, unclarified V8 agar $(21,30)$. After 3 days of incubation at $21 \pm 2{ }^{\circ} \mathrm{C}$ under fluorescent lighting, microbial growth was assessed by microscopy. Cultures that were suspected to be $P$. capsici based on morphological characteristics were transferred to new BARP plates and single-zoospore cultures were generated (18). Axenic cultures were incubated for 7 days on V8 agar with continual fluorescent lighting under ambient 
laboratory conditions $\left(21 \pm 2^{\circ} \mathrm{C}\right)$. Cultures were positively identified as $P$. capsici based on morphological characteristics described in the 1963 Phytophthora spp. key by Waterhouse (37). Additionally, the identification of $P$. capsici was supported by the $>80 \%$ marker homology with other known $P$. capsici isolates using amplified fragment length polymorphism (AFLP) analysis. This technique is described further in the DNA extraction and AFLP analysis section of the Materials and Methods.

Koch's postulates and pathogenicity to cucumber fruit. To confirm the pathogenicity of $P$. capsici isolates from bean, single-zoospore (axenic) cultures of six randomly selected $P$. capsici isolates were used to inoculate 103 -week-old snap bean plants (cv. HyStyle) with 7-mm-diameter mycelial agar plugs on leaf tissue. After symptoms developed, 5 to 7 days post inoculation (dpi), tissue at the margin of healthy and diseased was excised, surface sterilized, and plated onto BARP for incubation at $24^{\circ} \mathrm{C}$ under fluorescent lighting at room temperature for 3 days. Based on morphological characteristics (as stated above), the organism was identified as $P$. capsici and confirmation of pathogenicity on bean was completed. Bean plant inoculations to fulfill Koch's postulates were conducted two times. In our initial tests to fulfill Koch's postulates, we determined that $P$. capsici disease could not be incited through zoospore suspension inoculations made to the soil or to aboveground plant parts. Also, under greenhouse conditions, disease could not be incited when air temperatures were $>23^{\circ} \mathrm{C}$. For this reason, all inoculations on bean plants were carried out under ambient laboratory conditions $\left(21 \pm 2^{\circ} \mathrm{C}\right)$.

Twenty $P$. capsici isolates from green snap bean (Oceana County field 1) were used to inoculate 'Fanfare' (Stokes Seeds Limited, Buffalo, NY) cucumber fruit harvested from plants that were grown at the Plant Pathology Farm at Michigan State University, East Lansing, in a field with no history of $P$. capsici infestation. Fruit were surface disinfested with sodium hypochlorite $(5 \%)$, rinsed with sterile water, and dried under ambient laboratory conditions $\left(21 \pm 2^{\circ} \mathrm{C}\right)(9)$. A 7-mm mycelial agar plug from a 7-day-old culture of each isolate was placed on the surface of intact fruit, covered with a sterile microcentrifuge tube, and sealed to the fruit with petroleum jelly (9). Fruit were incubated under ambient laboratory conditions (21 \pm $2^{\circ} \mathrm{C}$ ) for 3 days in trays containing a wet paper towel. Trays were covered with plastic wrap to maintain high humidity during incubation. Disease was assessed by measuring three lesion parameters: (i) the diameter of the water-soaked region at the leading edge of the lesion (hereafter referred to as lesion diameter); (ii) diameter of the region with visible $P$. capsici sporu- lation (white and powdery) within the lesion (hereafter referred to as sporulation diameter); and (iii) density of pathogen sporulation (relative number of sporangia per square centimeter of fruit surface) rated visually as $0=$ none, $1=$ light, $2=$ moderate, or $3=$ high (hereafter referred to as sporulation density) (9). Fruit tests were conducted twice and results averaged. The experiment was set up in a randomized complete block design with two blocks and subsampling (four subsamples per block). All fruit disease ratings were taken 3 days post inoculation. Means of the measured
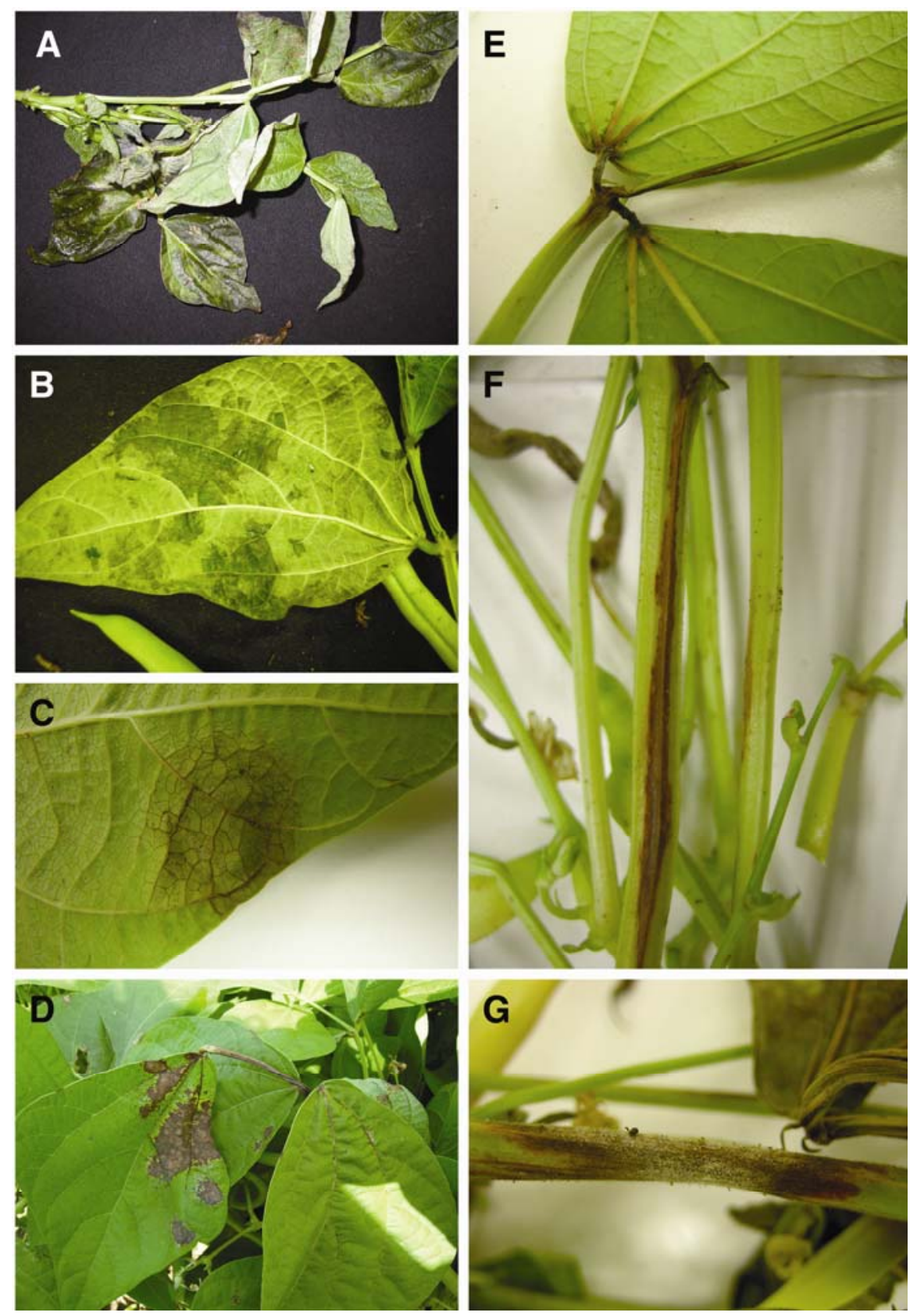

Fig. 2. Symptoms of Phytophthora capsici on snap bean leaves, petioles, and stems. A, Green snap bean 'HyStyle' from Oceana County, MI, 2003. Note water-soaking on leaves. B, Snap bean 'HyStyle' leaf from Cass County, MI, 2004. Note water-soaked leaf symptoms observed on leaf underside. C-G, Yellow snap bean 'Sunrae' from Van Buren County, MI, 2005. C, Circular necrotic lesion observed from leaf underside. D, Dark brown, necrotic leaf and petiole lesions. E, Necrotic symptoms spreading from junction of leaf and petiole. F, Brown, necrotic stem symptoms. G, Close up of stem lesion with pathogen sporulation on necrotic tissue.

ratings (lesion diameter and sporulation diameter) were separated and data were gukey's Studentized least SAS (SAS Institute, Cary, NC). The density of pathogen sporulation data (ordinal) were analyzed using the Kruskal-Wallis test $(P \geq 0.05)$ in SAS (SAS Institute).

Phenotypic characterization. Mating mm-diameter mycelial agar plug from the edge of an expanding single-zoosporederived culture was placed near the center of a V8 agar plate, $2 \mathrm{~cm}$ away from a plug

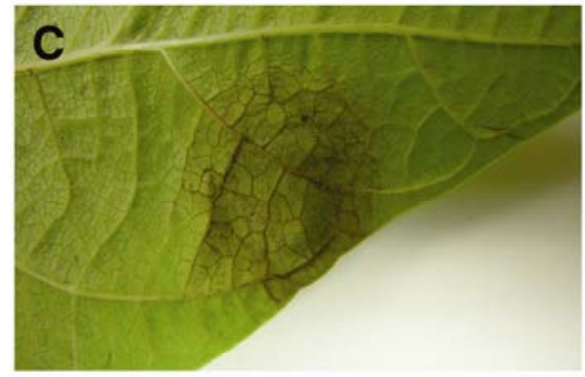

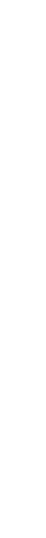


of either the standard A1 mating type (MT), isolate OP97, or the standard A2 MT, SP98. Plates were then incubated at $21 \pm 2{ }^{\circ} \mathrm{C}$ in the dark for 7 to 10 days. OP97 and SP98 are P. capsici isolates collected from diseased cucurbits from Michigan which are maintained in the laboratory of Dr. Mary Hausbeck of the Department of Plant Pathology at Michigan State University. OP97 and SP98 have been confirmed to be A1 and A2 using American Type Culture Collection standards. MTs were determined by assessing the presence or absence of oospores between the two agar plugs by microscopy (20).

Mefenoxam sensitivity. For each of the 680 isolates, a 7-mm-diameter mycelial agar plug from the edge of an expanding single-zoospore-derived culture was placed at the center of V8 plates (100 by $15 \mathrm{~cm}$ ) amended with mefenoxam (Ridomil Gold EC; $48 \%$ a.i., suspended in sterile distilled water, and added to molten V8 agar cooled to $49^{\circ} \mathrm{C}$ ) at 0 and $100 \mathrm{ppm}$. For each isolate, one 0 -ppm and two 100-ppm plates were inoculated and incubated at $21 \pm 2{ }^{\circ} \mathrm{C}$ under ambient laboratory lighting. Colony diameters were measured after 3 days. The colony diameters of the two 100-ppm plates were averaged prior to determining percent growth. Percent growth of an isolate on amended media was calculated by subtracting the inoculation plug diameter (7 $\mathrm{mm})$ from the diameter of each colony and dividing the average colony diameter of the amended plates by the average colony diameter of the unamended control plates: ([colony diameter on $100 \mathrm{ppm}$ V8 7-mm inoculation plug diameter]/[colony diameter on $0 \mathrm{ppm} \mathrm{V8} \mathrm{-} \mathrm{7-mm} \mathrm{inoculation}$ plug diameter]) $\times 100$. Isolates were assigned mefenoxam sensitivities based on percent growth of the control, as carried out by Lamour et al. (22). An isolate sensitive (S) to mefenoxam was $<30 \%$ of control, an intermediately sensitive (IS) isolate was 30 to $90 \%$ of control, and a resistant (R) isolate was $>90 \%$ of the control (22). All tests were conducted twice and results averaged.

Susceptibility of bean cultivars to $P$. capsici. Eleven cultivars of Phaseolus spp. and a single $G$. max cultivar (Table 1 ) were grown under greenhouse conditions and brought into the laboratory for susceptibility testing. Seven 3-week-old bean plants of each of the 12 cultivars selected were inoculated individually with one of six $P$. capsici isolates; the seventh plant was inoculated with a plug of V8 agar as a control. Isolates 9948, 9951, and 9974 obtained from Oceana County field 1 and isolates 9986, 9988, and 9989 from Oceana County field 2 were chosen. The six isolates selected were representative of unique phenotypic groups based on their symptom morphology on cucumber fruit and culture morphology on V8 agar. Mycelial agar plugs (7 $\mathrm{mm}$ in diameter) of 1week-old, single-zoospore-derived cultures were placed onto bean leaf tissue and covered with sterile microcentrifuge tubes sealed to the leaf surface with petroleum jelly. One plug was applied to the middle portion of the surface of a leaf. Individual plants were enclosed in a sealed clear plastic bag with a wet paper towel to maintain high humidity. Disease symptoms on bean could not be initiated at temperatures $>23^{\circ} \mathrm{C}$ in the greenhouse. For this reason, all inoculations were carried out at $21 \pm$ $2^{\circ} \mathrm{C}$ in the laboratory under ambient lighting and plants were rated for disease at 6 dpi. The disease rating for leaves was $0=$ no disease, $1=1$ to $20 \%$ necrosis, $2=21$ to $40 \%$ necrosis, $3=41$ to $60 \%$ necrosis, 4 $=61$ to $80 \%$ necrosis, and $5=81$ to $100 \%$ necrosis. The experiment was set up in one completely randomized trial with three repetitions. Disease ratings were analyzed using the Kruskal-Wallis test $(P=0.05)$ in SAS (SAS Institute).

DNA extraction and AFLP analysis. Genomic DNA from 131 isolates (from 2003 and 2004) was extracted from approximately $10 \mathrm{mg}$ of freeze-dried $P$. capsici mycelium using DNeasy mini-kits (Qiagen, Valencia, CA). Mycelium was grown in antibiotic-amended V8 broth and DNA was quantified on an agarose gel with known standards. EcoRI was obtained from Invitrogen (Carlsbad, CA), while MseI and T4 DNA ligase were obtained from Takara (Madison, WI). EcoRI and $M s e \mathrm{I}$ adapters and primers for ligation and amplification reactions were obtained from Integrated DNA Technologies (Coralville, IA). Sequence information for the adapters and primers is published in Vos et al. (36). The fluorescently labeled primers were obtained from Proligo (Boulder, $\mathrm{CO}$ ) and were composed of the EcoRI core sequence with and without selective nucleotides and either the WellRED D4-PA label (Proligo) or the WellRED D3-PA label at the $5^{\prime}$ end.

Restriction, ligation, preamplification, and selective amplification reactions were carried out as described by Habera et al. (11). Fluorescent products from the selective amplifications were analyzed on a CEQ 8000 Genetic Analysis System (Beckman Coulter, Fullerton, CA) using the manufacturer's protocols. A binary matrix was constructed scoring polymorphic fragments that were reproducible and distinct from nearby fragments and the baseline as either present (score 1) or ab-

Table 3. Analysis of Phytophthora capsici isolates identified from commercial bean fields in three Michigan counties during 2003 to 2005 by specific plant tissues

\begin{tabular}{lccccccc}
\hline \multirow{2}{*}{ Year, county } & \multicolumn{2}{c}{ Number of } & & \multicolumn{3}{c}{ No. of isolates from tissue (\% of total) } \\
\cline { 2 - 3 } \cline { 6 - 7 } & Plants $^{\mathbf{b}}$ & Isolates $^{\mathbf{c}}$ & & Stem & Leaf & Pod \\
\hline 2003, Oceana, field 1 & 50 & 20 & & $17(85)$ & $3(15)$ & 0 \\
2003, Oceana, field 2 & 50 & 29 & & $29(100)$ & 0 & 0 \\
2004, Cass & 100 & 227 & & $93(41)$ & $59(26)$ & $75(33)$ \\
2005, Van Buren & 200 & 404 & & $137(34)$ & $43(11)$ & $224(55)$ \\
\hline
\end{tabular}

${ }^{a}$ P. capsici isolates from various plant tissues; indicates that no $P$. capsici was identified on root tissue.

b Total number of plants sampled.

c Total number of $P$. capsici isolates.

Table 2. Phytophthora capsici isolates identified from commercial bean cultivars in Michigan from 2003 to $2005^{\mathrm{a}}$

\begin{tabular}{|c|c|c|c|c|c|c|c|c|}
\hline \multirow[b]{2}{*}{ Year } & \multirow[b]{2}{*}{ County } & \multirow[b]{2}{*}{ Cultivar } & \multirow[b]{2}{*}{ Isolates $^{\mathrm{c}}$} & \multirow[b]{2}{*}{ MT $^{\mathbf{d}}$} & \multicolumn{3}{|c|}{ Mefenoxam (Ridomil Gold) sensitivity ${ }^{b}$} & \multirow[b]{2}{*}{ Total } \\
\hline & & & & & $\mathbf{I}$ & IS & $\mathbf{S}$ & \\
\hline \multirow[t]{2}{*}{2003} & Oceana, field 1 & HyStyle green snap bean & 20 & A1 & 0 & 1 & 13 & 14 \\
\hline & - & & & A2 & 0 & 0 & 6 & 6 \\
\hline \multirow[t]{2}{*}{2003} & Oceana, field 2 & HyStyle green snap bean & 29 & A1 & 0 & 3 & 14 & 17 \\
\hline & & & & A2 & 1 & 1 & 10 & 12 \\
\hline \multirow[t]{2}{*}{2004} & Cass & HyStyle green snap bean & 227 & $\mathrm{~A} 1$ & 5 & 39 & 8 & 52 \\
\hline & & & & A2 & 40 & 60 & 75 & 175 \\
\hline \multirow{2}{*}{2005} & Van Buren & Sunrae yellow snap bean & 404 & $\mathrm{~A} 1$ & 92 & 98 & 73 & 263 \\
\hline & $\ldots$ & $\ldots$ & $\ldots$ & A2 & 31 & 70 & 40 & 141 \\
\hline Total & $\ldots$ & $\ldots$ & 680 & $\ldots$ & 169 & 272 & 239 & 680 \\
\hline
\end{tabular}

\footnotetext{
${ }^{a}$ Mating type (MT) and mefenoxam sensitivity are characterized for each isolate.

${ }^{\mathrm{b}}$ Indicates isolate sensitivity to the fungicide mefenoxam: insensitive (I), intermediately sensitive (IS), and sensitive (S).

${ }^{c}$ Total number of isolates.

${ }^{\mathrm{d}}$ Indicates mating type (A1 or A2) of isolate.
} 
sent (score 0). Unweighted pair group with mathematical averaging similarity analysis and dendrogram construction was performed using NTSYSpc 2.11a (Exeter Software, Setauket, NY). Isolates with identical AFLP profiles were considered to be members of the same clonal lineage.

\section{RESULTS}

Sample collection and pathogen identification. Overall disease symptoms on green and yellow snap bean included wilting and death of plants, especially those located in low-lying areas of the field and along the surface water drainage pattern (Fig. 1A). Water-soaked lesions, necrosis, and wilting of stem, petiole, and leaf tissue (Fig. 2) typically were observed. Disease symptoms on pods included water-soaked lesions, necrosis, shriveling, and pathogen sporulation (Fig. 1B-D). Most roots appeared healthy; however, some exhibited disease symptoms that were caused by other pathogens, including Fusarium spp. $P$. capsici was not isolated from excised root tissue. The average air temperature in Oceana and Cass Counties prior to and during the period of $P$. capsici detection (late July 2003 and early August 2004) was $18^{\circ} \mathrm{C}$. In late July, the average air temperature in Van Buren County was $23^{\circ} \mathrm{C}$.

The 49 P. capsici isolates obtained from the Oceana County fields (Table 2) were predominantly $(>85 \%)$ from stem tissue (Table 3). Although the foliage exhibited water-soaked lesions (Fig. 2A and B), the
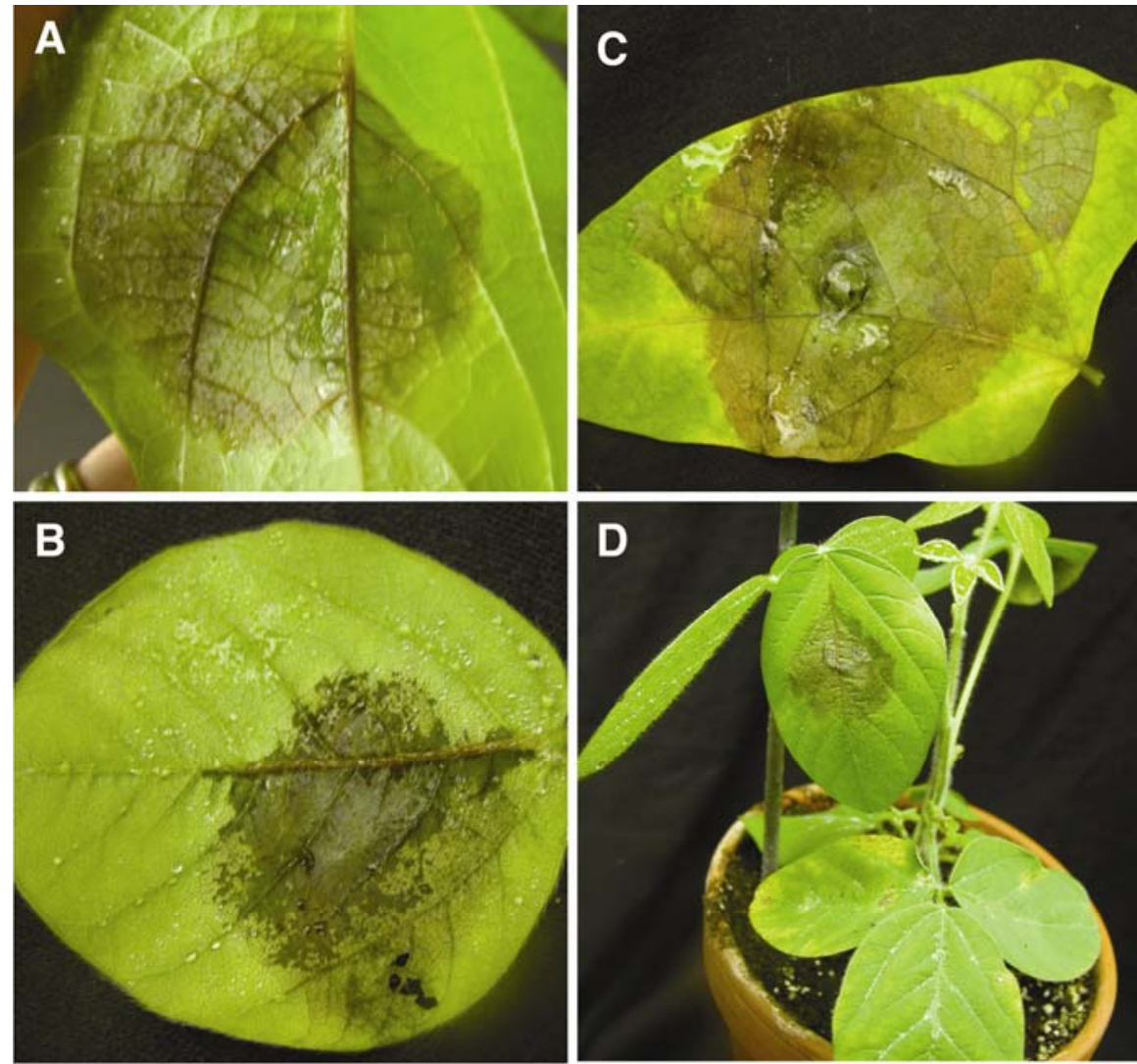

Fig. 4. Localized water-soaked foliar lesions on bean cultivars caused by Phytophthora capsici from Oceana County, MI green snap bean in 2003 (field 1). Lesions are depicted at 5 days post inoculation under laboratory conditions. Symptoms of localized water-soaking and necrosis are evident on A, 'Bush Tenderpod', B, soybean (leaf underside), C, 'Bush Lima', and D, soybean (leaf surface).
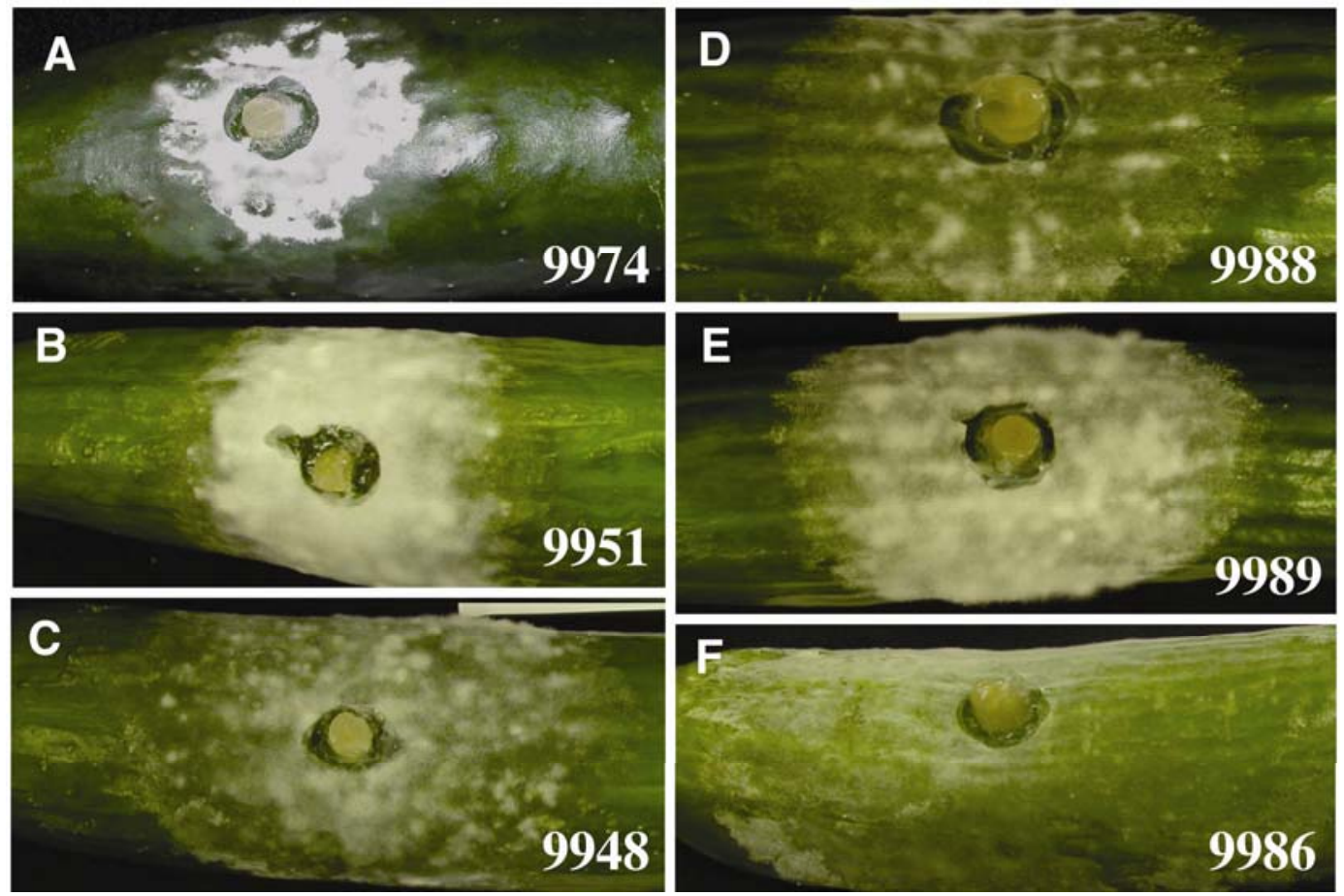

Fig. 3. Variation in 'Fanfare' cucumber fruit lesions (at 4 days post inoculation) from inoculation with six select Phytophthora capsici isolates from Oceana County, MI green snap bean, 2003. A-C, Lesions from P. capsici isolates from field 1. Lesions vary from A, sunken and covered in dense pathogen sporulation, which remains appressed to fruit surface, to $\mathbf{B}$, fluffy with dense aerial mycelium. C, Lesion of large diameter with fluffy aerial mycelium. D-E, Lesions from P. capsici isolates from field 2. Lesions with $\mathbf{D}$, moderate and $\mathbf{E}$, dense aerial mycelium. F, Lesion of largest diameter (when compared with A-E) and moderate appressed pathogen sporulation. Numbers in the lower right-hand corners of images indicate the isolate number. 
pods were healthy. In all, 227 isolates were collected from sampling of a green snap bean field in Cass County (Table 2) from stem, leaf, and pod tissues (Fig 1C and D); most isolates were obtained from stem tissue (Table 3). In all, 404 isolates of $P$. capsici were obtained from yellow snap bean sampled from a field in Van Buren County (Table 2) from stem, leaf, and pod tissues (Figs. 2C-G and 1B). The incidence and severity of disease on the pods was significant in this field, with $55 \%$ of the total isolates obtained from pod tissue (Table 3). P. capsici was positively identified based on morphological characteristics. Identification was supported by a $>80 \%$ marker homology with other known $P$. capsici isolates using AFLP analysis.

Koch's postulates and pathogenicity on cucumber fruit. The six isolates of $P$. capsici from snap bean from Oceana County in 2003 were pathogenic on HyStyle snap bean plants, causing foliar symptoms identical to those observed in commercial bean fields. $P$. capsici isolates from snap bean collected in Oceana County in 2003 were also all pathogenic on 'Fanfare' cucumber fruit. Disease symptoms on cucumber fruit inoculated with $20 P$. capsici isolates from snap bean developed water-soaked lesions with pathogen sporulation (Fig. 3); symptoms were comparable with those observed when fruit were inoculated with isolates from cucumber. On both snap bean plants and cucumber fruit, all isolates tested were pathogenic with no significant differences between $P$. capsici isolates. On cucumber fruit, however, phenotypic variation in sporulation density and mycelium morphology was observed (Fig. 3). Isolate 9974 from Oceana County field 1 produced fruit lesions that were water-soaked and sunken with dense, appressed pathogen sporulation (Fig. 3A). Representative isolates from Oceana County fields 1 and 2 (9951 and 9989) (Fig. 3B and E) produced fruit lesions with aerial mycelia and sporangia that appeared white and fluffy, whereas lesions from isolates 9948, 9988, and 9986 (Fig. 3C, D, and F) had large diameters and prolific pathogen sporulation with limited aerial mycelium.

Phenotypic characterization. $P$. capsici isolates from snap bean collected in Oceana and Van Buren Counties were primarily of the A1 MT (Table 2). Cass County isolates, however, were more than $75 \%$ A2 MT (Table 2). Most (80\%) isolates from Oceana County fields were sensitive to the fungicide mefenoxam (Table 2). A smaller percentage of isolates from Cass and Van Buren Counties were sensitive to mefenoxam; intermediately sensitive isolates comprised 42 to $44 \%$ of the population sampled, with 20 to $32 \%$ of the sampled population resistant to mefenoxam (Table 2).

Susceptibility of bean cultivars to $P$. capsici. All 12 bean cultivars (Table 1) inoculated with select $P$. capsici isolates (9948, 9951, 9974, 9986, 9988, and 9989) exhibited water-soaked lesions and necrosis of leaf tissue at 6 dpi (Fig. 4A-D). All bean cultivars tested appeared to be equally susceptible to $P$. capsici infection with no significant differences between $P$. capsici isolates. Under experimental conditions, the pathogen did not sporulate on bean tissues.

DNA extraction and AFLP analysis. AFLP analysis of $131 P$. capsici isolates (from 2003 and 2004) from Michigan snap bean indicated that there was similarity of isolates from individual counties and specific years (Fig. 5). Groups I and II included isolates from Cass County (Fig. 5). Within group I there were 15 unique AFLP profiles represented by more than one isolate (i.e. clones); in group II, just five unique AFLP profiles were found to be clonal (Fig. 5). Group III included isolates from both fields in Oceana County and represented three clonal lineages (Fig. 5). Of the 24 Cass County isolates fingerprinted, $14(58 \%)$ were unique (Fig. 5). There were $37(35 \%)$ unique isolates from Van Buren County (Fig. 5). There does not appear to be a subdivision in the population of $P$. capsici based on plant tissue or host. Each of the 23 clonal lineages included $P$. capsici isolates collected from multiple bean plant tissues (Table 4). Segments of electropherograms from AFLP profiles indicated that a $P$. capsici isolate from pumpkin (Oceana County, MI, 1997) had AFLP markers in common with isolates from snap bean from both Cass and Oceana Counties (Fig. 6).

\section{DISCUSSION}

Producers of cucurbitaceous, solanaceous, and leguminaceous crops are con-

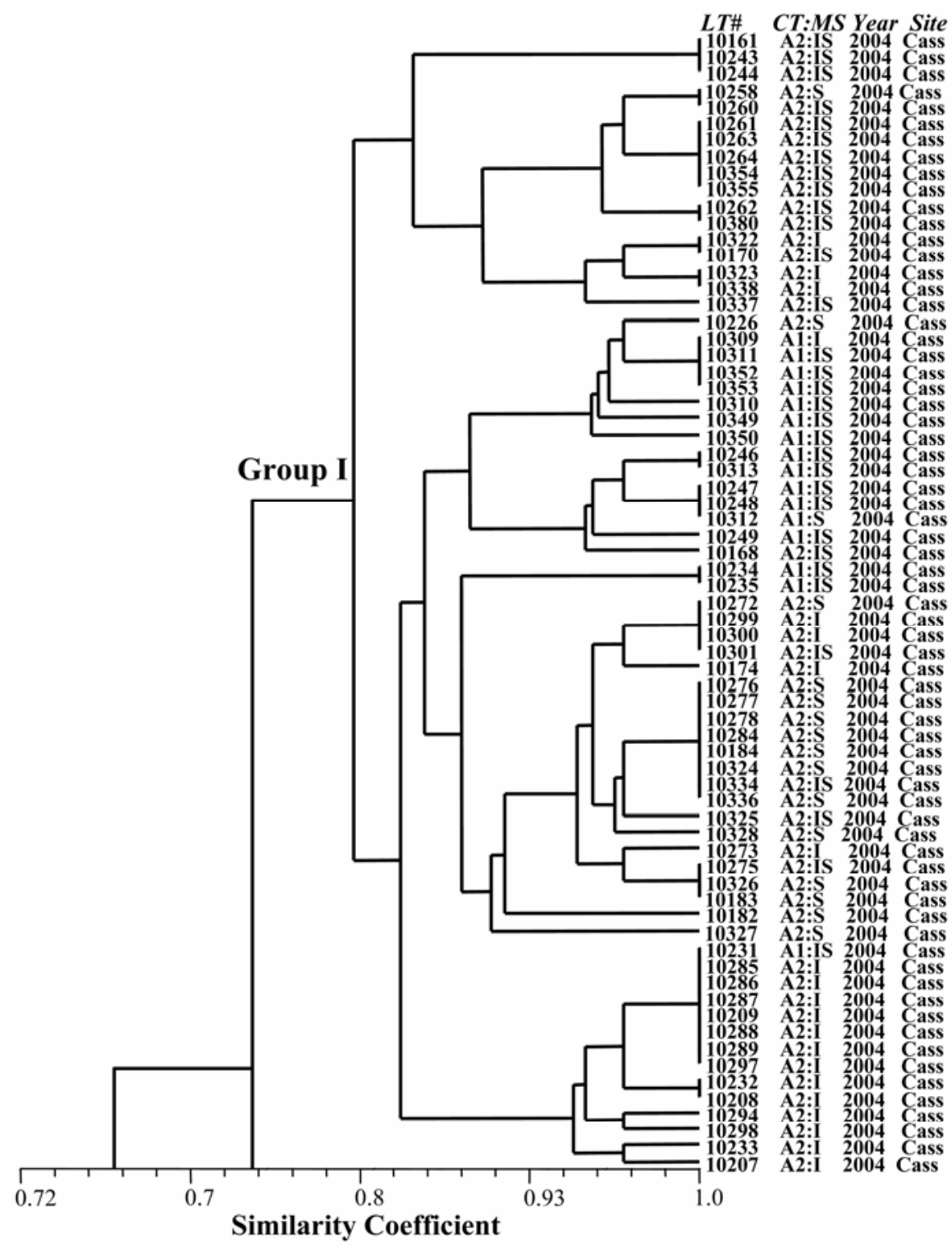

(Continued on next page)

Fig. 5. Cluster analysis of Phytophthora capsici isolated from Michigan green snap bean. Long-term numbers (LT\#) refer to culture identification numbers. Mating types (MTs) are either A1 or A2. Mefenoxam sensitivity (MS) characteristics are sensitive (S), intermediately sensitive (IS), or resistant (R). 
cerned with the new finding of $P$. capsici on bean in Michigan. Although P. capsici has had a greater impact on cucurbitaceous and solanaceous crops, causing an estimated loss of up to $25 \%$ of the state's value of susceptible vegetables when weather favors disease (12), the potential impact on Michigan's 2.2 million acres of bean crops raises new concerns for disease management and crop rotation. P. capsici caused an estimated crop loss of approximately $10 \%$ (personal communication with grower) on green snap bean in three sampled fields (each $\leq 50$ acres) in Michigan in 2003 and 2004. In 2005, P. capsici caused markedly worse disease than in the previous 2 years in a sampled yellow snap bean field (approximately 250 acres) in Michigan. Yellow snap bean exhibited severe pod disease incidence and severity, with an estimated loss of approximately one-third of the total crop (personal communication with grower). Preceding the disease outbreaks in each of the 3 years, there were rainfall events and periods of extended leaf wetness with high relative humidity.

P. capsici was isolated only from aboveground plant tissues; root sampling did not yield $P$. capsici. When bean plants were inoculated in the laboratory with a zoospore soil drench, root infection did not occur. Cucumber plants also appear to tolerate root infection by $P$. capsici, exhibiting no symptoms or limited root rot (12). In some cases, plant root exudates are essential for chemotactic attraction and encystment of Phytophthora spp. zoospores $(6,7)$. Further studies are needed to determine whether these exudates are limited or absent in bean roots, thereby making them less susceptible to $P$. capsici. Direct inoculation of $P$. capsici mycelial plugs on leaves and petioles resulted in HyStyle and other bean cultivars developing water-soaked lesions on leaves, foliar wilting, and complete plant death. It is likely that disease occurred in the field when infested soil was splashed up onto bean foliage and pods, or when pods made direct contact with the soil. The greatest crop loss occurred when pods became blighted.

Most growers of snap beans also raise vegetables; beans (snap bean and soybean) having been included as rotational crops to limit the soil build up of $P$. capsici. Beans, however, are not planted in Michigan just as rotational crops; snap beans, dry beans, and soybeans are raised as primary crops with a commodity value of $\$ 522$ million in 2005 (16). Despite crop rotation, $P$. capsici pressure in agricultural soils has increased over time, resulting in recurring disease with increasing severity $(19,20)$. The present, in-depth study of $P$. capsici on commercial snap bean, along with reports of $P$. capsici on lima bean in Argentina and the mid-Atlantic region $(5,8)$, indicate that adjustments in current rotational schemes are needed.

The $P$. capsici isolates collected from Michigan snap beans exhibited variation in

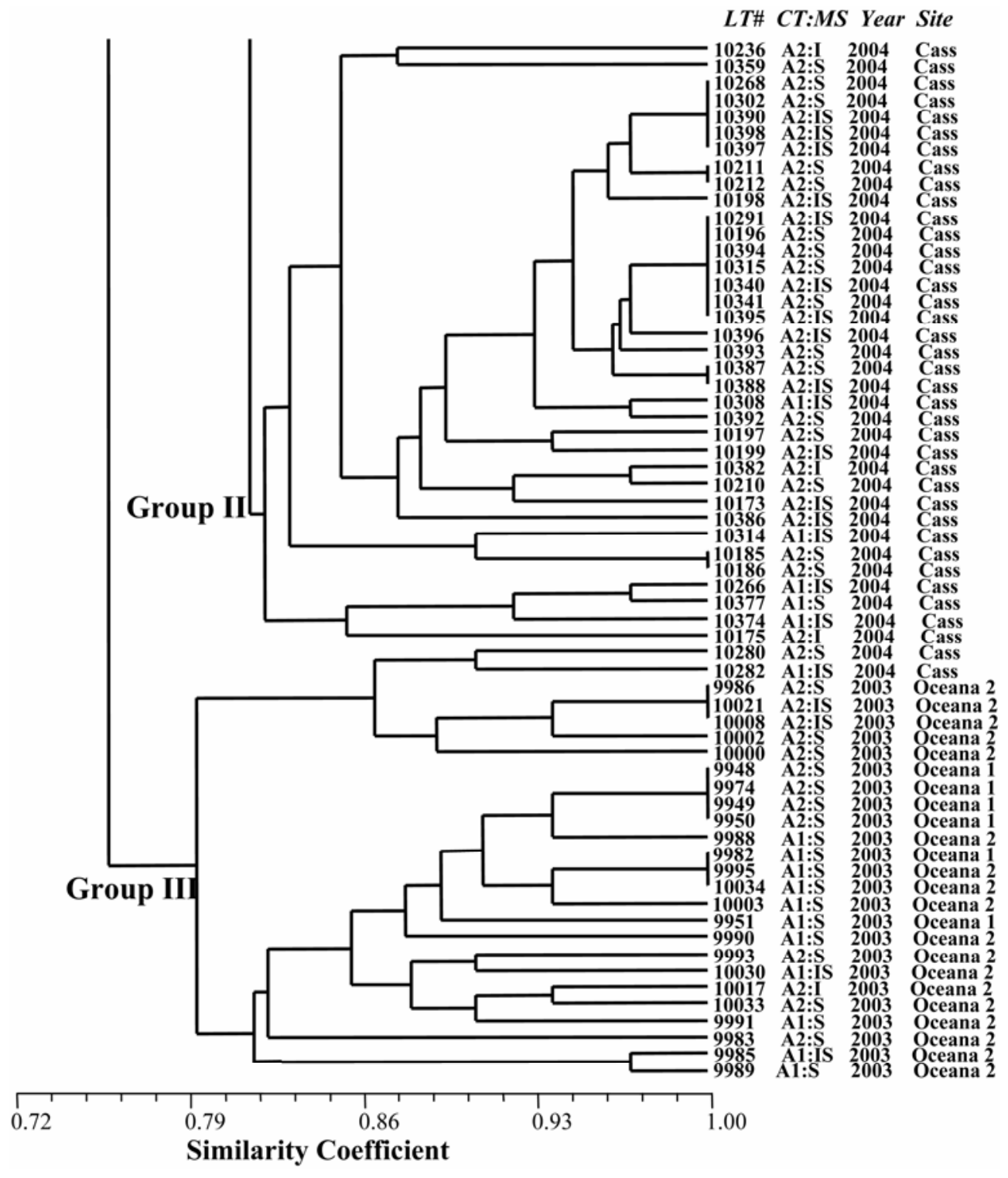

Fig. 5. (Continued from previous page) 
Table 4. Bean plant tissue diversity of amplified fragment length polymorphism (AFLP) similarity groups of Phytophthora capsici isolates from Oceana and Cass Counties, MI in 2003 and 2004

\begin{tabular}{|c|c|c|c|c|}
\hline \multirow[b]{2}{*}{ Cluster, subgroup } & \multicolumn{3}{|c|}{ Bean plant tissue } & \multirow[b]{2}{*}{ Total similarity $^{b}$} \\
\hline & Pod & Stem & Leaf & \\
\hline \multicolumn{5}{|l|}{ Group I } \\
\hline 1 & 1 & 2 & 0 & 3 \\
\hline 2 & 2 & 0 & 0 & 2 \\
\hline 3 & 3 & 0 & 2 & 5 \\
\hline 4 & 2 & 0 & 0 & 2 \\
\hline 5 & 2 & 0 & 0 & 2 \\
\hline 6 & 1 & 1 & 0 & 2 \\
\hline 7 & 0 & 4 & 0 & 4 \\
\hline 8 & 0 & 2 & 0 & 2 \\
\hline 9 & 0 & 3 & 0 & 3 \\
\hline 10 & 0 & 2 & 0 & 2 \\
\hline 11 & 0 & 4 & 0 & 4 \\
\hline 12 & 2 & 6 & 0 & 8 \\
\hline 13 & 1 & 2 & 0 & 3 \\
\hline 14 & 6 & 2 & 0 & 8 \\
\hline 15 & 1 & 1 & 0 & 2 \\
\hline \multicolumn{5}{|l|}{ Group II } \\
\hline 1 & 1 & 4 & 0 & 5 \\
\hline 2 & 0 & 2 & 0 & 2 \\
\hline 3 & 6 & 1 & 0 & 7 \\
\hline 4 & 0 & 2 & 0 & 2 \\
\hline 5 & 2 & 0 & 0 & 2 \\
\hline \multicolumn{5}{|l|}{ Group III } \\
\hline 1 & 0 & 3 & 0 & 3 \\
\hline 2 & 0 & 4 & 0 & 4 \\
\hline 3 & 0 & 3 & 0 & 3 \\
\hline
\end{tabular}

a Cluster groups have approximately $80 \%$ of 28 polymorphic markers assayed in common, whereas the similarity subgroups have $100 \%$ in common.

b Total number of isolates in similarity subgroup.
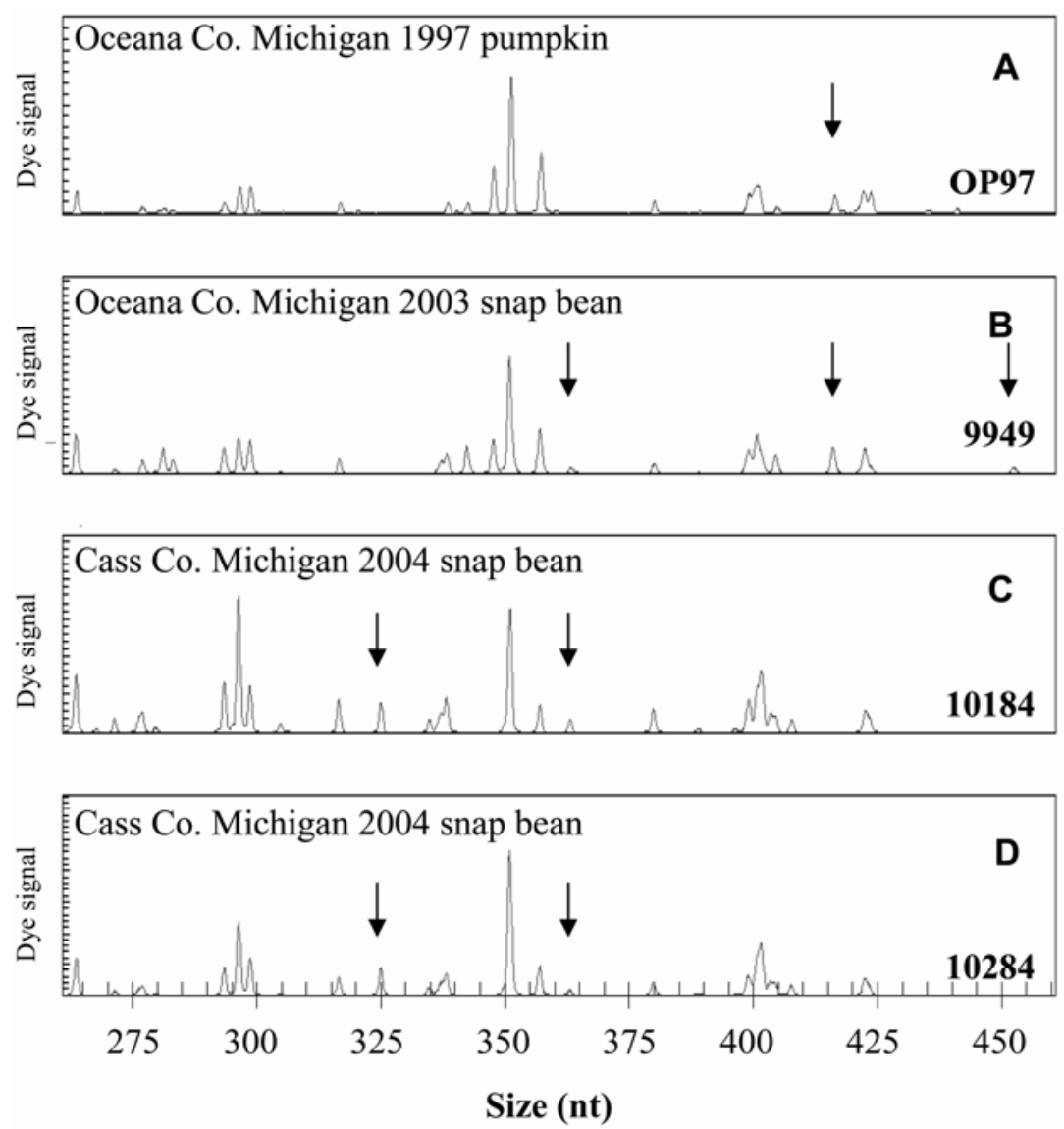

Fig. 6. A-D, Segments of electropherograms from amplified fragment length polymorphism (AFLP) profiles of genomic DNA from four Phytophthora capsici isolates recovered from pumpkin and green snap bean in Michigan. The AFLP profiles were produced using a Beckman-Coulter CEQ capillary genetic analysis system with the primer pair E-AC/M-CA and visualized using the CEQ fragment analysis software. Arrows indicate polymorphic markers of 325, 362, 415, and 452 nucleotides. phenotype and resistance to mefenoxam. All isolates were highly aggressive on leaves of all bean cultivars tested. Isolates also were pathogenic on cucumber fruit, a crop grown on 38,000 acres in Michigan, with variation in pathogen phenotype. Field populations of $P$. capsici from solanaceous and cucurbitaceous hosts are reported to have variation in virulence and other phenotypic characteristics (1315,23). The presence of A1 and A2 MTs in all of the snap bean fields sampled suggests that sexual recombination likely is occurring and that genetic diversity is being maintained within field populations. $P$. capsici isolates from Oceana County were predominantly sensitive to the fungicide mefenoxam, suggesting that use of this fungicide in the sampled fields likely has been judicious. Lamour and Hausbeck studied a $P$. capsici field population from Oceana County from 1998 to 2000 (20); all but one of the isolates examined were sensitive to mefenoxam. In our study, isolates from Cass and Van Buren Counties exhibited some sensitivity to mefenoxam; however, a large percentage of the populations were intermediately sensitive and resistant to the fungicide. The Cass and Van Buren County bean fields had been intensively cropped to pickling cucumber prior to being planted to bean crops.

The $P$. capsici responsible for disease outbreaks in Michigan snap bean during 2003 through 2005 likely was introduced previously and increased by intensive cucurbit production. In addition, these fields have a history of $P$. capsici incidence and extensive mefenoxam use. The fields were rotated to snap bean to avoid or limit vegetable crop losses to P. capsici, because disease pressure was high and mefenoxam resistance limited management options. A previous Michigan study indicated that a $P$. capsici epidemic on squash in 1999 was initiated by oospores generated 5 years previously, despite rotation to corn and soybean (19). The longevity of oospores makes it important to prevent the introduction of $P$. capsici to soils. Once infestation occurs, plant disease caused by $P$. capsici is a persistent risk if susceptible crops are planted and environmental conditions are favorable.

AFLP profiling of $P$. capsici isolates from snap bean in Michigan indicated the absence of host specificity or pathogen population subdivision based on host. Diversity measured via AFLP markers indicated that markers carried by isolates recovered from cucurbit hosts in Michigan also are carried by the isolates recovered from bean cultivars. In addition, all bean isolates were pathogenic on cucumber fruit, causing symptoms that were identical to those produced by $P$. capsici isolates from cucurbit hosts. It appears that the $P$. capsici isolates from snap bean are not unique but are part of resident populations in these fields that can infect other suscep- 
tible crops. Also, the pathogen populations were not divided based on bean tissue; clonal isolates were recovered from pods, stems, and leaves.

Commercial snap bean production for processing typically is less profitable than vegetable production, and fungicide applications may not be an economically viable option for Phytophthora disease management. Currently, growers have a limited number of fungicides with restricted labeling available for use on snap bean in managing seedling blight caused by Phytophthora and Pythium spp. However, in general, labeling does not include foliar application. Development of genetic resistance could allow continued bean production in fields infested with $P$. capsici. A portion of the large-acre yellow snap bean field sampled in 2005 was planted to green Romano bean which did not exhibit disease symptoms and did not yield $P$. capsici when sampled. These cultivar differences may have been influenced by weather conditions or soil inoculum; however, genetic resistance may be a factor. Screening under controlled conditions is needed to determine whether there are significant differences among bean cultivars. Under laboratory conditions, all snap bean $P$. capsici isolates tested were pathogenic on the foliage of the 12 bean cultivars inoculated, including soybean, indicating that most bean cultivars grown in rotation with cucurbitaceous or solanaceous crops may be at risk. In the past, rotation with bean cultivars was an option for growers with fields infested with $P$. capsici; however, this practice is no longer recommended.

\section{ACKNOWLEDGMENTS}

We thank our grower cooperators and K. I. Cervantes for technical assistance with cultures. In addition, we acknowledge the support of the MDA Michigan Specialty Crop Block Grant for Pickling Cucumber; Pickle Seed Research Fund, Pickle Packers International, Inc.; Pickle and Pepper Research Committee of Michigan State University, Pickle Packers International, Inc.; Michigan State University Project GREEEN, Generating Research and Extension to meet Economic and Environmental Needs (a cooperative effort by plant-based commodities and businesses with Michigan State University Extension, the Michigan Agricultural Experiment Station, and the Michigan Department of Agriculture): Developing strategy to limit Phytophthora diseases on vegetables; Gerber Products Company: Managing diseases of snap beans 20032004; and the United States Department of Agriculture CSREES Special Research Grant Award No. 2006-34572-16902 (Phytophthora Research, MI).

\section{LITERATURE CITED}

1. Alconero, R., and Santiago, A. 1972. Characteristics of asexual sporulation in Phytophthora palmivora and Phytophthora para- sitica nicotianae. Phytopathology 62:993-997.

2. Bernhardt, E. A., and Grogan, R. G. 1982. Effect of soil matric potential on the formation and indirect germination of sporangia of $P h y$ tophthora parasitica, P. capsici, and P. cryptogea rots of tomatoes, Lycopersicon esculentum. Phytopathology 72:507-511.

3. Critopoulos, P. D. 1955. Foot rot of tomato incited by Phytophthora capsici. Bull. Torrey Bot. Club 82(3):168-182.

4. Crossan, D. F., Haasis, F. A., and Ellis, D. E. 1954. Phytophthora blight of summer squash. Plant Dis. Rep. 38:557-559.

5. Davidson, C. R., Carroll, R. B., Evans, T. A., and Mulrooney, R. P. 2002. First report of Phytophthora capsici infecting lima bean (Phaseolus lunatis) in the mid-Atlantic region. Plant Dis. 86:1049.

6. Erwin, D. C., Bartnicki-Garcia, S., and Tsao, P. H. 1983. Phytophthora: Its Biology, Taxonomy, Ecology, and Pathology. American Phytopathological Society Press, St. Paul, MN.

7. Erwin, D. C., and Ribeiro, O. K. 1996. Phytophthora Diseases Worldwide. American Phytopathological Society Press, St. Paul MN.

8. Frezzi, M. J. 1950. Las especies de Phytophthora en la Argentina. Rev. Invest. Agríc. 4 (1):47-134.

9. Gevens, A. J., Ando, K., Lamour, K. H., Grumet, R., and Hausbeck, M. K. 2006. A detached cucumber fruit method to screen for resistance to Phytophthora capsici and effect of fruit age on susceptibility to infection. Plant Dis. 90:1276-1282.

10. Gevens, A. J., and Hausbeck, M. K. 2004. Phytophthora capsici isolated from snap beans is pathogenic to cucumber fruit and soybean. (Abstr.) Phytopathology 95:S162.

11. Habera, L., Smith, N., Donahoo, R., and Lamour, K. 2004. Use of a single primer to fluorescently label selective amplified fragment length polymorphism reactions. BioTechniques 37:902-904

12. Hausbeck, M. K., and Lamour, K. H. 2004. Phytophthora capsici on vegetable crops: Research progress and management challenges. Plant Dis. 88:1292-1303.

13. Hwang, B. K., and Kim, C. H. 1995. Phytophthora blight of pepper and its control in Korea. Plant Dis. 79:221-227.

14. Islam, S. Z., Babadoost, M., Lambert, K. N., and Ndeme, A. 2005. Characterization of Phytophthora capsici isolates from processing pumpkin in Illinois. Plant Dis. 89:191-197.

15. Kim, E. S., and Hwang, B. K. 1992. Virulence to Korean pepper cultivars of isolates of Phytophthora capsici from different geographic areas. Plant Dis. 76:486-489.

16. Kleweno, D. D. Michigan Agricultural Statistics 2005-2006. U. S. Dep. Agric. Natl. Agric. Stat. Serv. Mich. Dep. Agric. PR-06-48.

17. Ko, W. 1988. Hormonal heterothallism and homothallism in Phytophthora. Annu. Rev. Phytopathol. 26:57-73.

18. Lamour, K. H., and Hausbeck, M. K. 2000. Mefenoxam insensitivity and the sexual stage of Phytophthora capsici in Michigan cucurbit fields. Phytopathology 90:396-400.

19. Lamour, K. H., and Hausbeck, M. K. 2001. The dynamics of mefenoxam insensitivity in a recombining population of Phytophthora capsici characterized with amplified fragment length polymorphism markers. Phytopathology 91:553-557.
20. Lamour, K. H., and Hausbeck, M. K. 2001. Investigating the spatiotemporal genetic structure of Phytophthora capsici in Michigan. Phytopathology 91:973-980.

21. Lamour, K. H., and Hausbeck, M. K. 2003. Effect of crop rotation on the survival of $P h y$ tophthora capsici in Michigan. Plant Dis. 87:841-845.

22. Lamour, K. H., and Hausbeck, M. K. 2003. Susceptibility of mefenoxam-treated cucurbits to isolates of Phytophthora capsici sensitive and insensitive to mefenoxam. Plant Dis. 87:920-922.

23. Lee, B. K., Kim, B. S., Chang, S. W., and Hwang, B. K. 2001. Aggressiveness to pumpkin cultivars of isolates of Phytophthora capsici from pumpkin and pepper. Plant Dis. 85:497-500.

24. Mchau, G. R. A., and Coffey, M. D. 1995. Evidence for the existence of two distinct subpopulations in Phytophthora capsici and a redescription of the species. Mycol. Res. 99:89102.

25. Oelke, L. M., Bosland, P. W., and Steiner, R. 2003. Differentiation of race specific resistance to Phytophthora root rot and foliar blight in Capsicum annuum. J. Am. Soc. Hortic. Sci. 128:213-218.

26. Polach, F. J., and Webster, R. K. 1972. Identification of strains and inheritance of pathogenicity in Phytophthora capsici. Phytopathology 62:20-26.

27. Ristaino, J. B., and Johnston, S. A. 1999. Ecologically based approaches to management of Phytophthora blight on bell pepper. Plant Dis. 83:1080-1089.

28. Satour, M. M., and Butler, E. E. 1967. A root and crown rot of tomato caused by Phy tophthora capsici and $P$. parasitica. Phytopathology 57:510-515.

29. Schlub, R. L. 1983. Epidemiology of Phytophthora capsici on bell pepper. J. Agric. Sci. 100:7-11.

30. Schmitthenner, A. F., and Bhat, R. G. 1994. Useful Methods for Studying Phytophthora in the Laboratory. OARDC, Wooster, $\mathrm{OH}$.

31. Schwartz, H. F. 2005. Downy mildew. In: Compendium of Bean Diseases, Second Edition. H. F. Schwartz, J. R. Steadman, R. Hall, and R. L. Forster, eds. American Phytopathological Society Press, St. Paul, MN.

32. Tamietti, G., and Valentino, D. 2001. Physiological characterization of a population of Phytophthora capsici Leon. from northern Italy. J. Plant Pathol. 83:199-205.

33. Tian, D., and Babadoost, M. 2004. Host range of Phytophthora capsici from pumpkin and pathogenicity of isolates. Plant Dis. 99:485489.

34. Tucker, C. M. 1931. Taxonomy of the Genus Phytophthora DeBary. University of Missouri, Columbia.

35. Uchida, J. Y., and Aragaki, M. 1980. Chemical stimulation of oospore formation in Phy tophthora capsici. Mycologia 72:1103-1108.

36. Vos, P., Hogers, R., Blecker, M., Reijans, M., van der Lee, T., Hornes, M., Frijters, A., and Pot, J. 1995. AFLP: a new technique for DNA fingerprinting. Nucleic Acids Res. 23:44074414.

37. Waterhouse, G. M. 1963. Key to the species of Phytophthora de Bary. Mycol. Pap. No. 92. Commonwealth Mycol. Soc., Kew, Surrey, England. 